\title{
Indonesia and Counter Illegal, Unreported, and Unregulated (IUU) Fishing in Southeast Asia
}

\author{
L Y Arnakim ${ }^{1}$, N Shabrina ${ }^{2}$ \\ ${ }^{1}$ Faculty of Humanities, Universitas Bina Nusantara, Jakarta, Indonesia \\ ${ }^{2}$ Independent researcher and graduate of University of Malaya, Kuala Lumpur-Kepulauan \\ Riau, Indonesia \\ ${ }^{1}$ lili.yulyadi@binus.edu
}

\begin{abstract}
As one of the world's richest countries for aquatic resources, Indonesia naturally becomes a popular target for both fishing, which is often done outside the legal framework. Indonesia acknowledged this illegal extraction of natural resources as a real threat to the country. Illegal fishing is considered environmental crime that poses a threat to sustainability of the environment. This paper examines how far Indonesia has managed environmental security issues in Southeast Asia by looking at the roles and contributions of the country in countering the illegal fishing. By using both primary and secondary data, the authors attempt to assess the roles undertaken by Indonesia in dealing with illegal, unreported, and unregulated fishing. It found that Indonesia has been very much active in fighting against IUU fishing in its maritime territory. The country is an initiator to some daring measures, most notably the "blowing up and sinking" illegal fishing vessels found in its waters. The government also initiated a regulation where it only allows local ships to fish in its waters. All of these initiatives are vital to help the region in dealing with irregular migration that is often associated with human trafficking, and also in dealing with IUU Fishing and conservation of aquatic resources.
\end{abstract}

Keywords: Fishing, IUU, Illegal

\section{INTRODUCTION}

Illegal fishing is considered environmental crime that poses a threat to sustainability of the environment and is likely to result in environmental scarcity. Illegal fishing activities would also be detrimental to food supply and security [1]. As one of the world's richest countries for aquatic resources, Indonesia naturally becomes a popular target for both fishing, which is often done outside the legal framework. Indonesia acknowledged this illegal extraction of natural resources as a real threat to the country, as stipulated in the 2015 Defence White Paper [2]. The concern that Indonesia's fish will be in danger of being exhausted by illegal fishing is further exacerbated with the frequent use of unsafe fishing practices by both local and foreign fishermen [3].

Fishing industry forms an important share to Indonesian economy, contributing $3 \%$ to the national GDP and it is one of the main sources of income for at least 6 million Indonesians [4]. With the rampant illegal and unregulated fishing usually performed by foreign countries like China, Vietnam, Thailand and Malaysia, Indonesia suffered an annual loss to at least US\$24 
billion [5]. The actual cost would likely to be higher, since the estimation did not take into account other values like tax income and ecosystem damage [6].

Indonesia's vast and porous maritime territory makes it difficult for the government to monitor safety in its waters, especially with having only limited number of patrol boats to deal with the plentiful illegal and unidentified fishing vessels [6]. This shows that Indonesia's rich natural asset can actually be a source of weakness. The concept of ketahanannasionalmentions how natural aspects including natural resources such as fish and marine products can be used to achieve social and economic prosperity for a nation state. However, it does not tell us how richness in natural resources can instead invite illegal activities to operate such as IUU Fishing that pose a threat to national defense and produce socio-economic problems like food insecurity and economic loss. As such, the government of Indonesia has continuously improved its legal mechanism and enforcement to effectively deal with IUU.

\section{METHOD}

The paper is qualitative in nature. It uses both primary and secondary sources of data collection. Primary data refers to "original data source, that is, one in which the data are collected firsthand by the researcher for a specific research purpose or project"[7]. Secondary data sources, on the other hand, are "preexisting data that have been collected for a different purpose or by someone other than the researcher. These data may have been gathered originally for another research or administrative purposes"[8].

As for data analysis, the researcher applies thematic analysis to assist in qualitative analysis of data. By utilizing this method of data analysis, the researcher will be able to gain insight and knowledge on the role of Indonesia in countering illegal, unreported, and unregulated fishing in Southeast Asia. Similarly the data gathered through the interviews conducted with the informants. Similarly, the data gathered from secondary sources will also be analyzed and interpreted in such a way that will enable the author to identify roles and contributions of Indonesia in dealing with environmental security issues.

\section{RESULT AND DISCUSSION}

There are some strategies to counter illegal fishing.

\subsection{Legal Measures and Enforcement Mechanism on Fisheries}

In Indonesia, the main legal framework for fisheries is the Law No. 31/2004 (as amended by the Law No. 45/2009). The amendment was made to achieve utilization of fish resources that would contribute to an improvement of a living standard. With this amendment, the government of Indonesia has introduced some procedures to achieve optimum level of management, control, and law enforcement system for fishery. For example, in managing fishing environment, Article 9 of the Law No. 45/2009 prohibits the use of catching means that are disturbing and damaging to the continuity of fish resources. Violation of this article would incur the perpetrator a maximum of five years imprisonment and a fine of a maximum of 2 billion Rupiah [9]. This helps the government to protect aquatic resources from being damaged by unsafe practices of fishing.

The Minister in charge of fishery (now the Ministry of Marine Affairs and Fisheries) holds the right to control over fishery management, such as determining the permissible kind, amount, and measurement of fish; and also to prevent pollution and damages to fish and its 
environment. This kind of control would allow the state to prevent overfishing and also to conserve and maintain the "quality, diversity and availability of fishery resources" for present and future generations, which is in line with the principles for FAO Code of Conduct for Responsible Fisheries, where Indonesia is a member to the International agreement [10]. This is also a form of Indonesia's compliance with the Article 61 on conservation of the living resources of the UNCLOS [11]. In other words, the regulation will help the country to achieve food security and sustainable development of its finite resources.

It is within the authority of the Ministry to issue permit letters, notably for fish catching (SuratIzinPenangkapanIkan, SIPI), fishing ship (SuratIzinKapalPengangkutIkan, SIKPI), and fishery business (SuratIzin Usaha Perikanan, SIUP)[9]. The Minister also has the right to impose administrative sanctions for an IUU convict "in the form of warning, freezing of permit, or revocation of permit" (Article 35A). Fishing vessels shall have sailing approval letter and operations feasibility letter. Any ship or person who fails to show the required documents or is found to have forged the documents during search or investigations by the authorities will be given jail term and fine as sanctions. Still in the management system, Article 41 of the Law obligates every fish catching ship and fish transporting ship to land its catches at the designated ports (as per permit), otherwise, administrative sanctions will be imposed by the authority. Each of the designated ports is being supervised by a harbormaster as appointed by the government. In managing and controlling fishery issues, the Ministry shares some power to the regional governments of Indonesia.

In terms of enforcement mechanism, Article 66C of the 2009 Law gives the authority to fishery controller (a civil employee appointed by the government) to "stop, investigate, bring, detain, arrest" a ship or a person suspected of committing IUU in Indonesian waters until the case is transferred to a criminal case investigator. According to Article 73 of the Law, a criminal case investigator is either from the government civil employee, Indonesian Navy officer, or Indonesian Police officer, who has the authority to perform investigation on fishery issues. Furthermore, the 2009 Law established a special Fishery Court to deal with IUU, which has jurisdiction to process a case involving both foreigners and Indonesian citizens [9]. These Articles are some of the examples of how Indonesian government deals with IUU by applying thorough regulations on fishing activities in its maritime territory. The government has applied several mechanisms that act as a deterrence to IUU, such as imprisonment, fine, and administrative sanctions.

\subsection{National Plan of Action}

Indonesia has formulated its own National Plan of Action on To Prevent and to Combat Illegal, Unreported, and Unregulated Fishing for 2012-2016. This plan of action acts as a guidance for the relevant institutions in the country to improve their work in dealing with IUU fishing. In the document, it was stated that the government pledges to improve the country's surveillance, to integrate and better coordinate fisheries management system among relevant agencies, and to maintain consistency and transparency in applying sanction against perpetrators of IUU fishing. This national plan of action was a form of compliance by Indonesia to the International and the Southeast Asia's regional plan of action on IUU fishing.

\subsubsection{Reform Under Jokowi’s Administration}

Maritime issues, including IUU Fishing, are under the spotlight more than ever during JokoWidodo's presidency, due to the president's vision to make Indonesia a global maritime 
power. One of the five main agendas of the president's maritime policy is to improve "management of Indonesia's oceans and fisheries through the development of the country's fishing industry and building maritime food sovereignty and security"[12]. Better regulations and more effective preventive and law enforcement strategies are thus integral to the achievement of the country's vision of being a global maritime power and also to live up to its status as the world's largest archipelagic state.

Under his administration, the president who is better known as Jokowi has two important actions to fight against illegal fishing in its territory. First, the government performs a crackdown on illegal fishers or what some called as the "shock therapy" campaign by capturing and "blowing up and sinking" illegal fishing vessels found in Indonesian waters [13]. According to Ministry of Marine and Fishery of Indonesia, the crackdowns by Indonesian authorities resulted in an increase of the number of captured foreign vessels committing IUU from only 32 in 2013 to 115 in 2014 [5].

In 2016, it was reported that Indonesian government has "exploded and sunk" 174 illegal fishing boats in its waters since the beginning of Jokowi's term in 2014 [14]. Although it may appear harsh to some people, the government's action is actually still within the nation's legal framework. Article 69(4) of the Law No. 45/2009 states "...the investigator and/or Fishery Controller is entitled to take special actions in the form of burning and/or sinking a fishing ship flying a foreign flag based on sufficient initial proof" [9]. On a positive note, this move was said to have a positive impact in preventing the conduct of illegal fishing from taking place in the country. Furthermore, Langenheim (2015) argued that this unprecedented move could help Indonesia to "revolutionize" its fisheries management, if consistently applied [15].

The second move is in the form of administrative functions. The Minister of marine and fishery of Indonesia issued two most notable decrees in management of fishery. The first one was the Ministerial Decree No. 56/2014. This regulation put a moratorium on the issuance of new fishing permits from November 2014 to April 2015 [16]. The second one is the Ministerial Decree No. 57/2014, which put at-sea transshipment in Indonesian waters on halt [17]. In other words, transshipment is only allowed at the ports provided by the government. This regulation seems to be valid today, since there was no expiry date mentioned in the Decree. Ministry of Marine Affairs and Fisheries released another regulation in form of an official memo to ban foreign-made vessels from operating in Indonesian waters [18]. By allowing fishing in its waters only to local ships, the government of Indonesia will have a greater control over fishing activities in its maritime territory.

All of the government's initiatives above are important to protect Indonesia's marine resources from being overfished by unlawful actors and also to ensure food security and diversity for present and future generations of Indonesia. In the aspect of enforcement, President Jokowi established Indonesia's National Maritime Security Board (BAKAMLA) through Presidential Decree No. 178/2014 [19]. BAKAMLA is mandated with a duty to conduct "security and safety patrol in Indonesian waters", with some functions including surveillance, monitoring, and prevention of violations of law in Indonesian maritime territory [20]. In addition, the President also formed "Task Force 115" specially designed to deal with eradication of IUU in Indonesian waters. However, this formation was not well received by many, as it was seen to create redundancy in law enforcement system to combat IUU [21].

\subsection{Collaborative Actions}

Cooperation in combating IUU Fishing will support Indonesia's "maritime diplomacy" effort in achieving one of the main priorities in Indonesia's development agenda (nawacita) i.e. 
to "strengthening national identity as a maritime nation"[22]. Through interstate cooperation, Indonesian government would be able to intensify law enforcement and supervision of IUU fishing for eliminating security concerns over illegal fishing and breach of sovereignty.

In its 2012-2016 National Plan of Action to prevent and combat IUU fishing, Indonesia affirmed its willingness to cooperate with other nations, especially in joint patrols and information exchange with neighboring countries, and also in the field of research and development. In the National Plan of Action, it was stated that the government of Indonesia has been actively engaged in bilateral cooperation with other countries like Australia, Malaysia and Vietnam.

Indonesia is also in the process of negotiation with Thai government to form bilateral cooperation on fisheries and labour [23]. This Indo-Thai bilateral cooperation is a positive move, knowing Thai fishing fleet has often used Indonesian waters to perform IUU fishing to meet the global demand for its fish product. Thailand is one of the world's leading seafood exporters. However, the country was revealed to frequently conduct IUU fishing in foreign waters and its fishery industry has also been involved in labor exploitation and trafficking, prompted European Union to give an ultimatum to ban Thai seafood products from entering European market [24].

In addition, Indonesia also cooperates in technology transfer with developed countries. For example, in 2015, Norwegian government agreed to transfer the country's more advanced monitoring and technological capabilities to help the government of Indonesia in its dealing with illegal fishing [25]. With this kind of effort, Indonesia would be able to enhance Indonesia's capability in surveillance of its maritime territory to prevent criminal acts such as IUU fishing from taking place. In multilateral cooperation, Indonesia is a member of IORA. As mentioned earlier in chapter 4, IORA works to address maritime security issues. Other than piracy, IORA's fields of cooperation also cover issues related to fisheries management and conservation in the Indian Ocean region[26].

\section{CONCLUSION}

In the context of IUU Fishing, Indonesia plays an important role to guard its maritime environment against unlawful acts that would endanger the sustainability of its aquatic resources. This is reflected in the national policy on environmental protection that promotes safe and proper fishing. Indonesia also safeguards its territorial sovereignty by introducing various measures that could put a restraint to the conduct of fishing by foreign vessels. Besides, Indonesia works to ensure food sovereignty by promoting sustainable fishing on its maritime territory.

Compared to other maritime issues, Indonesia seems to be more aggressive in combating illegal fishing. Indonesia seems to have taken many unprecedented initiatives, such as the "shock therapy" campaign by capturing and "blowing up and sinking" illegal fishing vessels found in Indonesian waters and also banning foreign-made vessels from operating in Indonesian waters. By allowing fishing in its waters only to local ships, the government of Indonesia will have a greater control over fishing activities in its maritime territory. The government of Indonesia, especially under Jokowi's presidency, has shown stronger commitment to combat IUU Fishing when the country's Maritime and Fisheries Minister asked international support to wage war against the security issue. The Minister encouraged members of the United Nations to address the issue of IUU Fishing as a part of transnational crimes as the issue meets the characteristics of what considered as a transnational crime. This move is seen necessary to increase public attention on the issue of IUU Fishing and hence 
would enhance the effectiveness of counter measures adopted by affected countries such as Indonesia.

IUU Fishing is, however, difficult to handle. Not only it is related to other forms of transnational crime such as human trafficking, but its law enforcement mechanism is also said to be infected with corruption, where perpetrators would often bribe Indonesian officials in order to use Indonesian waters without fear of getting prosecuted. It is then understandable that Indonesian government tends to perceive IUU as a transnational organized crime rather than a mere environmental security. Because, it sees that if it is treated as transnational crime, the issue will be given more attention, more sufficiently studied, will be better defined and criminalized, and international cooperation on this field could be further enhanced [38].

If Indonesia were able to implement the principles drawn in the plan, the country would be able to contribute to regional and international effort in achieving conservation of world's aquatic resources. This connotation is similar to the principle of "one world, one ocean" coined by the Minister of Marine Affairs and Fisheries of Indonesia, which means the "destruction of fish stocks in one country will always affect other countries". As a result, Indonesia is a victim to IUU fishing conducted by foreign countries, including nearby countries such as Thailand, Vietnam and Malaysia. Due to this differing nature of the problem, Indonesia has seriously responded to the issue.

Indonesia is very much active in fighting against IUU fishing in its maritime territory. The country is an initiator to some daring measures, most notably the "blowing up and sinking" illegal fishing vessels found in its waters. The government also initiated a regulation where it only allows local ships to fish in its waters. All of these initiatives are vital to help the region in dealing with irregular migration that is often associated with human trafficking, and also in dealing with IUU Fishing and conservation of aquatic resources. Illegal fishing is one of the main concerns of Indonesia because the country's vast sea territory with rich natural endowments is attracting foreign vessels from neighboring countries to come and illegally extract the resources, causing a threat of fish depletion to the country.

\section{REFERENCES}

[1] ASEAN Studies Program, "Talking ASEAN on Illegal Fishing," ASEAN Studies Program, 2015. [Online]. Available: https://thcasean.org/read/news/154/TalkingASEAN-on-Illegal-Fishing.

[2] Kemhan RI, "Buku Putih Pertahanan Indonesia," Kementerian Pertahanan Republik Indonesia, 2015. [Online]. Available: https://www.kemhan.go.id/wpcontent/uploads/2016/04/BPPI-INDO-2015.pdf.

[3] J. Maloney, "IUU Fishing Implications in Indonesia Public Policy Indonesia," Public Policy Indonesia, 2017. [Online]. Available: https://publicpolicyindonesia.wordpress.com/2017/01/13/iuu-fishing-implications-inindonesia/.

[4] S. Axbard, "Income Opportunities and Sea Piracy in Indonesia: Evidence from Satellite Data," Am. Econ. J. Appl. Econ., vol. 8, no. 2, pp. 154-194, Apr. 2016.

[5] I. Girdansah and A. Priamarizki, "Indonesia's Maritime Doctrine and Security Concerns RSISPolicy Report," Rajaratnam School of International Studies, 2015. [Online]. Available: https://www.rsis.edu.sg/wpcontent/uploads/2015/04/PR150409_Indonesias-Maritime-Doctrine.pdf.

[6] Heriyanto, "Illegal Fishing Costs Indonesia 3 Billion Dollars a YearReporting ASEAN," Asean News, 2012. [Online]. Available: http://www.aseannews.net/illegal- 
fishing-costs-indonesia-3-billion-dollars-a-year/.

[7] N. J. Salkind, Encyclopedia of Research Design. Thousand Oaks: Sage Publications Inc, 2010.

[8] D. S. Bell, “The Sage Encyclopedia of Qualitative Research Methods2009365Lisa M. Given. The Sage Encyclopedia of Qualitative Research Methods. Thousand Oaks, $\{C A\}:$ Sage Publications 2008. $, \quad\{$ ISBN $\}: \begin{array}{llllll}978 & 1 & 4129 & 6390 & 9\end{array}$ \{ltextsterling\}240/\{\textdollar\}435 Last visited May,” Ref. Rev., vol. 23, no. 8, pp. 24-25, 2009.

[9] Law, No. 45/2009 on Amendment to Law No. 31/2004 Concerning Fishery. .

[10] FAO, "Code of Conduct for Responsible Fisheries," Food and Agriculture Organization of United Nations, 1995. [Online]. Available: http://www.fao.org/docrep/005/v9878e/v9878e00.htm\#6.

[11] United Nations, "United Nations Convention on the Law of the Sea," United Nations, 1982. [Online]. Available: http://www.un.org/depts/los/convention_agreements/texts/unclos/unclos_e.pdf.

[12] B. Bandoro, "Indonesia’s Maritime Role Hinges on 'Pillars," Jakarta Globe, 2014. [Online]. Available: http://jakartaglobe.id/opinion/indonesia-maritime-role-hinges-onpillars/.

[13] C. Weatherby, "Indonesia's Global Maritime Nexus: Implications for Illegal Fishing," Stimson, 2014. [Online]. Available: https://www.stimson.org/content/indonesiasweather-forecast-hazy-with-a-chance-of-clear-skies.

[14] Antara, "Government to continue crackdown on illegal fishing: Minister," Antara News, 2016. [Online]. Available: https://en.antaranews.com/news/104017/government-to-continue-crackdown-onillegal-fishing-minister.

[15] J. Langenheim, "Indonesia's new marine laws threaten sustainable fisheries," The Guardian, 2015. [Online]. Available: http://www.theguardian.com/environement/thecoral-triangle/2015/jan/14/indoneia's-new-marine-laws-threaten-sustainable-fisheries.

[16] PERMEN-KP, "No. 56/2014 Peraturan Menteri Kelautandan Perikanan Republik Indonesia tentang Penghentian Sementara (Moratorium) Perizinan Usaha PerikananTangkap di Wilayah Pengelolaan Perikanan Negara Republik Indonesia.” .

[17] PERMEN-KP, "No. 57/2014 Peraturan Menteri Kelautan dan Perikanan Republik Indonesia tentang Perubahan Kedua atas Peraturan Menteri KElautan dan Perikanan No. PER.30/MEN/2012 tentang Usaha PerikananTangkap di Wilayah Pengelolaan Perikanan Negara Republik Indonesia.".

[18] C. Rogers, "End of the line for foreign-made fishing boats in Indonesia?," 2016.

[19] 1 O. Tamindae, "Indonesia committed towards eradicating illegal fishing," Antara News, $2015 . \quad$ [Online]. Available: http://www.antaranews.com/en/news/97299/indonesia-committed-towardseradicating-illegal-fishing.

[20] A. Setiawan, "PP No. 178/2014 on the Establishment of Maritime Security Board," Sekretariat Kabinet Republik Indonesia, 2015. [Online]. Available: http://setkab.go.id/en/pp-no-1782014-on-the-establishment-of-maritime-securityboard/.

[21] T. Salim, "Govt forms another anti-illegal fishing task force," 2015.

[22] Bappenas, "Medium Term Development Plan: RPJM 2015-2019 Directorate of Forestry and Water Resources Conservation," Bappenas, 2015. [Online]. Available: http://redd- 
indonesia.org/pdf/BAPPENAS_Forestry_and_Water_Ressources_UNORCID_Dialog ue_Series_9_March_2015.pdf.

[23] Ministry of Foreign Affairs of the Kingdom of Thailand, "Press Releases: Thailand's Progress in Combating IUU Fishing," Ministry of Foreign Affairs of the Kingdom of Thailand, 2016. [Online]. Available: http://www.mfa.go.th/main/en/mediacenter/14/64174-Thailand's-Progress-in-Combating-IUU-Fishing.html.

[24] Greenpeace Southeast Asia, "Turn the Tide: Human Rights Abuses and Illegal Fishing in Thailand's Overseas Fishing Industry," Greenpeace Southeast Asia, 2016. [Online]. Available: http://m.greenpeace.org/seasia/PageFiles/745330/Turn-The-Tide.pdf.

[25] N. Sambhi, “Jokowi's 'Global Maritime Axis': Smooth Sailing or Rocky Seas Ahead?," Secur. Challenges, vol. 11, no. 2, pp. 39-55, 2015.

[26] IORA, "Fisheries Management," Indian Ocean Rim Association. [Online]. Available: https://www.iora.int/en/priorities-focus-areas/fisheries-management. 